\title{
Sensing of Lead Ions by a Carboxylate-Substituted PPE:
}

\section{Multivalency Effects}

Ik-Bum Kim, Anna Dunkhorst, James Gilbert, and Uwe H. F. Bunz*

School of Chemistry and Biochemistry, Georgia Institute of Technology, 770 State St., Atlanta, GA 30332, USA. Fax: 01(404)385-1795; Tel: 01(404)385-1795; E-mail: uwe.bunz@chemistry.gatech.edu

\section{Electronic Supplementary Information (ESI)}

\section{Synthesis of Polymer 4 and Model Compound 5}

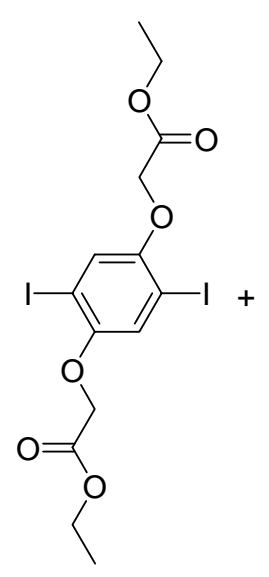

1

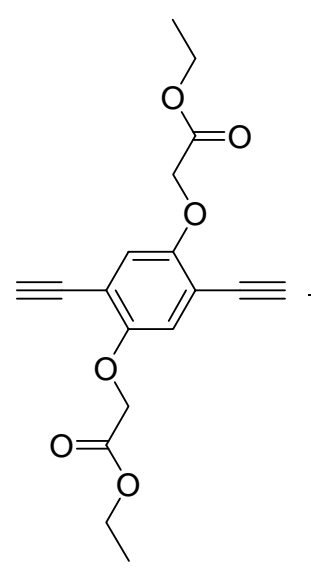

2

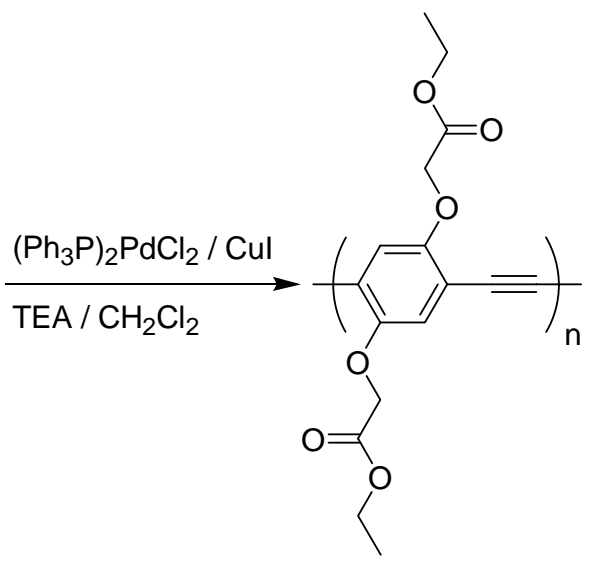

3

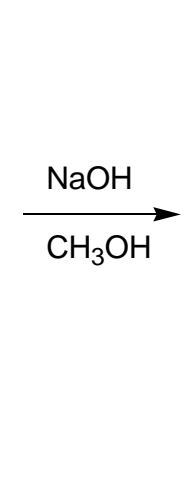

$=\mathrm{O}$

4

Synthesis of 1: 1,4-Diiodo-2,5-dihydroquinone (3.62 g, $10.0 \mathrm{mmol}),{ }^{1}$ 2-butanone (50 mL), potassium carbonate $(13.8 \mathrm{~g}, 100 \mathrm{mmol})$, and ethyl bromoacetate $(6.68 \mathrm{~g}, 40.0 \mathrm{mmol}$, commercially available, Aldrich) were placed in a $250 \mathrm{~mL}$ round bottom flask and heated to reflux for $24 \mathrm{~h}$. The mixture was allowed to cool to room temperature and the solvent was removed. The crude solid was crystallized from a mixture of ethyl acetate and hexane to yield pure 1 as a colorless solid (3.61 g, 68\%). ${ }^{1} \mathrm{H}$ NMR $\left(\mathrm{CDCl}_{3}\right): \delta 7.12(\mathrm{~s}, 2 \mathrm{H}), 4.58(\mathrm{~s}, 4 \mathrm{H}), 4.24(\mathrm{q}$, 
$4 \mathrm{H}), 1.27(\mathrm{t}, 6 \mathrm{H}) .{ }^{13} \mathrm{C} \mathrm{NMR}\left(\mathrm{CDCl}_{3}\right): \delta 167.77,152.56,123.49,86.15,67.28,61.52,14.23 . \mathrm{IR}$ : $v 2980,2933,1740,1477,1440,1379,1250,1226,1200,1086,1040,1032,755,721$.

Synthesis of 2: Diiodo monomer $1(2.14 \mathrm{~g}, 4.00 \mathrm{mmol})$ was dissolved in THF $(20 \mathrm{~mL})$ and triethylamine $(5 \mathrm{~mL})$ in a $50 \mathrm{~mL}$ round bottom flask. The solution was purged with nitrogen for $15 \mathrm{~min}$ and $\left(\mathrm{Ph}_{3} \mathrm{P}\right)_{2} \mathrm{PdCl}_{2}(28 \mathrm{mg}, 0.04 \mathrm{mmol})$, and $\mathrm{CuI}(7.6 \mathrm{mg}, 0.04 \mathrm{mmol})$ were added. The mixture was allowed to stir at room temperature for $24 \mathrm{~h}$. The mixture was filtered to remove the ammonium salts and the solvent mixture was removed in vacuo. The solid residue was dissolved in THF and a solution of tetrabutylammonium fluoride $(1 \mathrm{M})$ was added. The reaction mixture was stirred for $10 \mathrm{~min}$ at room temperature and the solvent was removed in vacuo. The product was isolated on a silica gel column (ethylacetate/hexane 1:3) as a pale yellow solid in 55 \% yield $(727 \mathrm{mg}) .{ }^{1} \mathrm{H}$ NMR $\left(\mathrm{CDCl}_{3}\right): \delta 6.91(\mathrm{~s}, 2 \mathrm{H}), 4.65(\mathrm{~s}, 4 \mathrm{H}), 4.25(\mathrm{q}, 4 \mathrm{H}), 3.38(\mathrm{~s}, 2 \mathrm{H})$, $1.28(\mathrm{t}, 6 \mathrm{H}) .{ }^{13} \mathrm{C} \mathrm{NMR}\left(\mathrm{CDCl}_{3}\right): \delta 168.14,153.45,118.48,113.77,83.50,78.84,66.75,61.47$, 14.21. IR: v 3259, 2977, 2909, 1756, 1500, 1436, 1393, 1278, 1239, 1216, 1081, 1025, 862, 726.

Synthesis of Polymer 3: Monomer $1(0.214 \mathrm{~g}, 0.400 \mathrm{mmol})$ and monomer $2(0.145 \mathrm{~g}, 0.440$ mmol) were dissolved in chloroform $(4 \mathrm{~mL})$ and triethylamine $(1 \mathrm{~mL})$ in an oven dried Schlenk flask. $\left(\mathrm{Ph}_{3} \mathrm{P}\right)_{2} \mathrm{PdCl}_{2}(1.4 \mathrm{mg}, 0.002 \mathrm{mmol})$ and $\mathrm{CuI}(0.4 \mathrm{mg}, 0.002 \mathrm{mmol})$ were added to the flask. The reaction mixture was stirred under the nitrogen at $50{ }^{\circ} \mathrm{C}$ for $72 \mathrm{~h}$. The solution was slowly added to ether $(100 \mathrm{~mL})$. The precipitate was washed with hot ether. An orange solid was obtained in $93 \%$ yield $(220 \mathrm{mg})$. The number average molecular weight was estimated to be $12 \times 10^{3}$ with a polydispersity $\left(\mathrm{M}_{\mathrm{w}} / \mathrm{M}_{\mathrm{n}}\right)$ of $4.26 .{ }^{1} \mathrm{H}$ NMR (DMSO- $\left.\mathrm{d}_{6}\right): \delta 7.16(\mathrm{~s}, 2 \mathrm{H}), 4.93(\mathrm{~s}$, 4H), $4.20(\mathrm{br}, 4 \mathrm{H}), 1.22$ (br, 6H). ${ }^{13} \mathrm{C}$ NMR (DMSO-d 6 ): $\delta 167.88,152.47,117.74,113.56$, 
91.21, 66.18, 60.18, 13.47. IR: v 2969, 2937, 2762, 2678, 2478, 2206, 1751, 1512, 1419, 1284, 1190, 1083, 1031, 861.

Synthesis of Polymer 4: A solution of $3(150 \mathrm{mg})$ and sodium hydroxide $(0.45 \mathrm{~g})$ in methanol $(25 \mathrm{~mL})$ was stirred at reflux temperature for $24 \mathrm{~h}$ and cooled in a refrigerator overnight. The precipitate was filtered and washed with methanol and ether yield 4 (130 mg) as a yellow powder. The polymer was purified by dialysis using $1 \mathrm{kD}$ MWCO cellulose membrane and recovered by Freeze-Dryer. The quantum yield of 4 in water is $7.98 \% .{ }^{1} \mathrm{H}$ NMR $\left(\mathrm{D}_{2} \mathrm{O}\right): \delta 7.08$ (s, 2H), $4.53(\mathrm{~s}, 4 \mathrm{H}) .{ }^{13} \mathrm{C}$ NMR $\left(\mathrm{D}_{2} \mathrm{O}\right): \delta 176.85,153.78,118.48,114.51,92.38,69.37$. IR: $v$ 3424, 2936, 2198, 1612, 1497, 1416, 1339, 1282, 1213, 1053, 863.

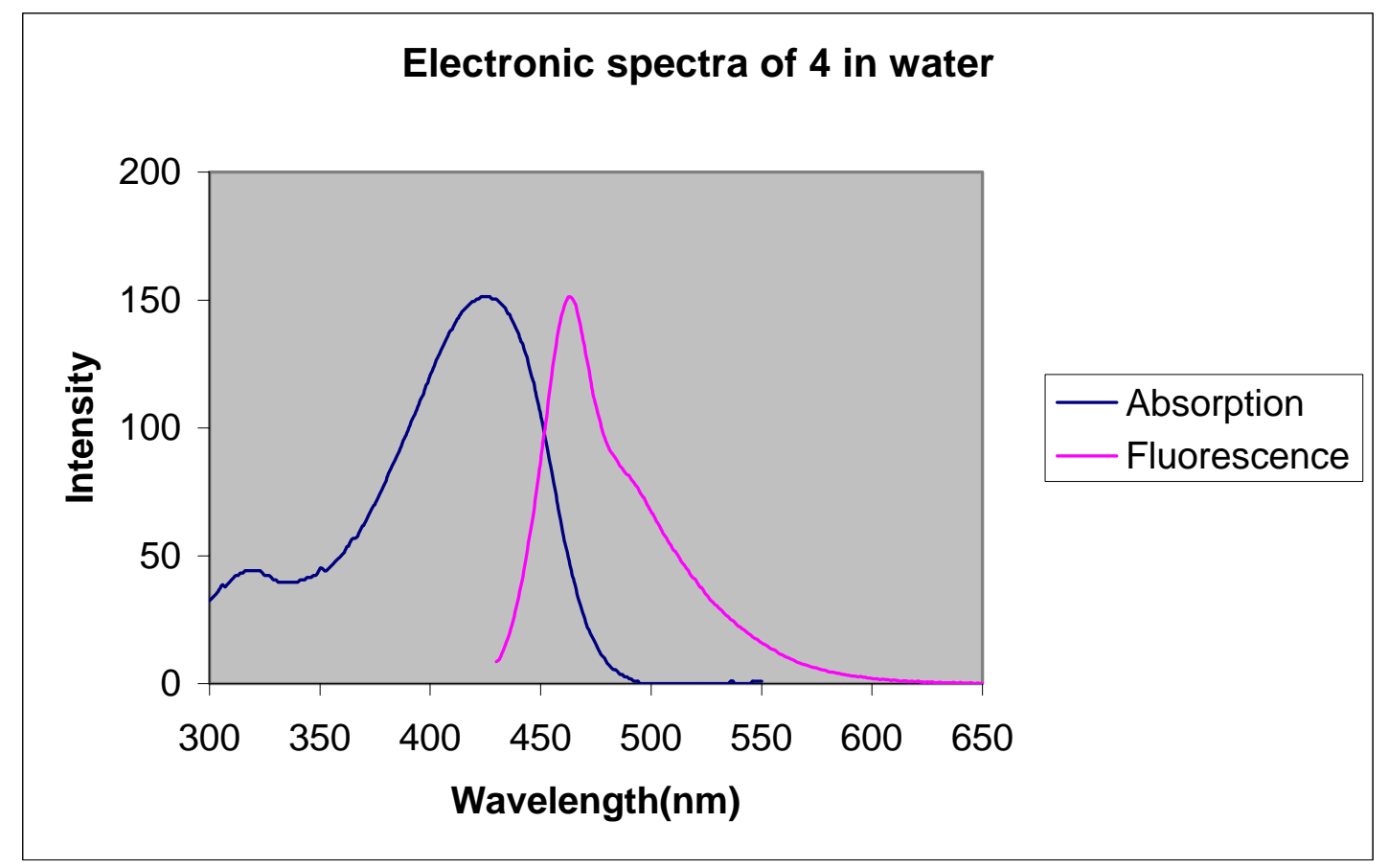




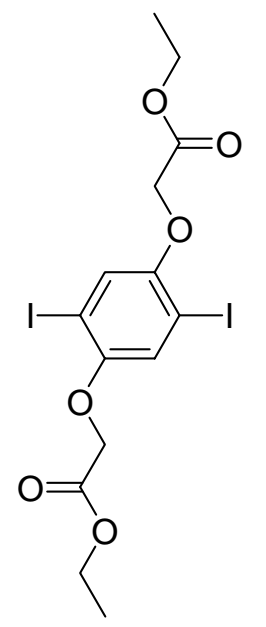

1
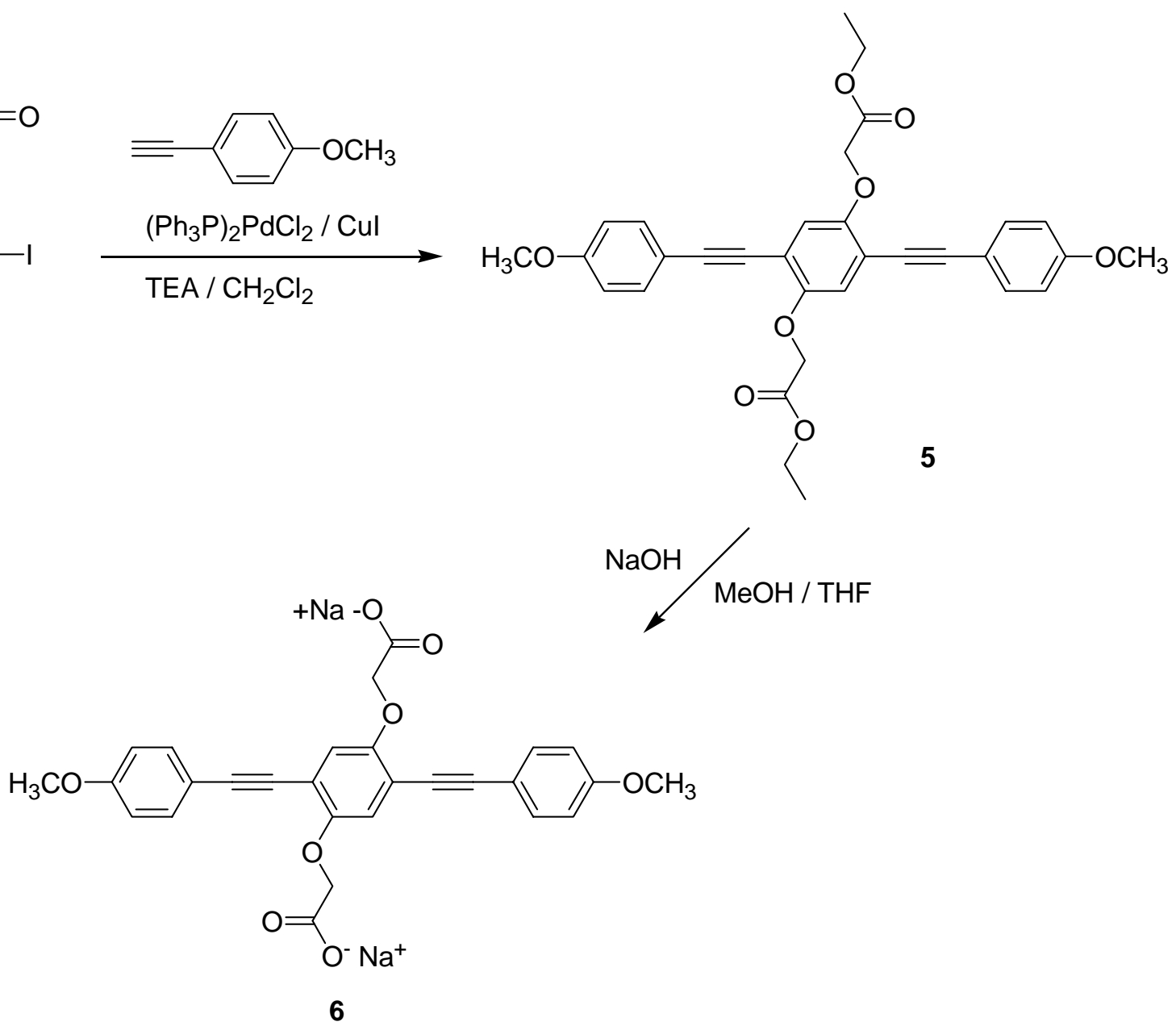

Synthesis of 5: Diiodo monomer 1 (534 mg, $1.00 \mathrm{mmol})$ and p-methoxyphenylacetylene (291 $\mathrm{mg}, 2.20 \mathrm{mmol})^{2}$ were dissolved in dichloromethane $(8 \mathrm{~mL})$ and triethylamine $(2 \mathrm{~mL})$ in a $25 \mathrm{~mL}$ round bottom flask. The solution was purged with nitrogen for $15 \mathrm{~min}$ and $\left(\mathrm{Ph}_{3} \mathrm{P}\right)_{2} \mathrm{PdCl}_{2}(7.0$ $\mathrm{mg}, 0.01 \mathrm{mmol})$, and $\mathrm{CuI}(1.9 \mathrm{mg}, 0.01 \mathrm{mmol})$ were added. The mixture was allowed to stir at reflux temperature for $24 \mathrm{~h}$. The mixture was filtered to remove the ammonium salts and the solvent mixture was removed in vacuo. The product was isolated on a silica gel column 
(ethylacetate/hexane 1:2) as a pale yellow solid in $65 \%$ yield $(350 \mathrm{mg}) .{ }^{1} \mathrm{H} \mathrm{NMR}\left(\mathrm{CDCl}_{3}\right): \delta$ $7.49(\mathrm{~d}, 4 \mathrm{H}), 6.97(\mathrm{~s}, 2 \mathrm{H}), 6.87(\mathrm{~d}, 4 \mathrm{H}), 4.70(\mathrm{~s}, 4 \mathrm{H}), 4.27(\mathrm{q}, 4 \mathrm{H}), 3.81(\mathrm{~s}, 6 \mathrm{H}), 1.29(\mathrm{t}, 6 \mathrm{H}) .{ }^{13} \mathrm{C}$ $\operatorname{NMR}\left(\mathrm{CDCl}_{3}\right): \delta 168.63,159.80,153.13,133.15,118.26,115.13,114.65,113.96,95.84,83.77$, 67.13, 61.33, 55.27, 14.15. IR: $v$ 2981, 2939, 2837, 1739, 1604, 1514, 1494, 1444, 1412, 1279, $1248,1197,1081,1029,858,833,733$.

Synthesis of 6: A solution of $5(100 \mathrm{mg}, 0.180 \mathrm{mmol})$ and sodium hydroxide $(660 \mathrm{mg}, 16.5$ mmol) in methanol $(15 \mathrm{~mL})$ and water $(1 \mathrm{~mL})$ was stirred at $80^{\circ} \mathrm{C}$ for $2 \mathrm{~h}$ and allowed to cool to room temperature. The solution was slowly added to diethyl ether $(150 \mathrm{~mL})$. The precipitate was filtered and washed with ether. A yellow powder was obtained in $75 \%$ yield $(73 \mathrm{mg})$. The quantum yield of 6 in water is $86.5 \%$. ${ }^{1} \mathrm{H}$ NMR $\left(\mathrm{D}_{2} \mathrm{O}\right): \delta 7.30(\mathrm{~d}, 4 \mathrm{H}), 6.74(\mathrm{~d}, 4 \mathrm{H}), 6.72(\mathrm{~s}$, 2H), $4.35(\mathrm{~s}, 4 \mathrm{H}), 3.63(\mathrm{~s}, 6 \mathrm{H}) .{ }^{13} \mathrm{C}$ NMR $\left(\mathrm{D}_{2} \mathrm{O}\right): \delta 176.67,159.67,152.59,133.67,117.26$, 115.11, 114.64, 113.60, 96.03, 84.85, 68.40, 55.78. IR: v 3289, 2944, 2839, 2202, 1604, 1460, $1410,1335,1292,1250,1207,1176,1029,865,833,687$. Decomp. $>200{ }^{\circ} \mathrm{C}$.

\section{References:}

1) Zhou, Q.; Swager T. M. J. Am. Chem. Soc. 1995, 117, 12593-12602

2) Vasilevski, S. F.; Klyatskaya, S. V.; Elguero, J. Tetrahedron 2004, 60, 6685-6688. 
Figure 1. Stern-Volmer constants of the quenching experiments of polymer 4 in $0.1 \mathrm{M} \mathrm{KClO}_{4}$ and PIPES* buffer (0.05M, $\mathrm{pH}=7.2)$.

\section{PPE-COOH in PIPES buffer}

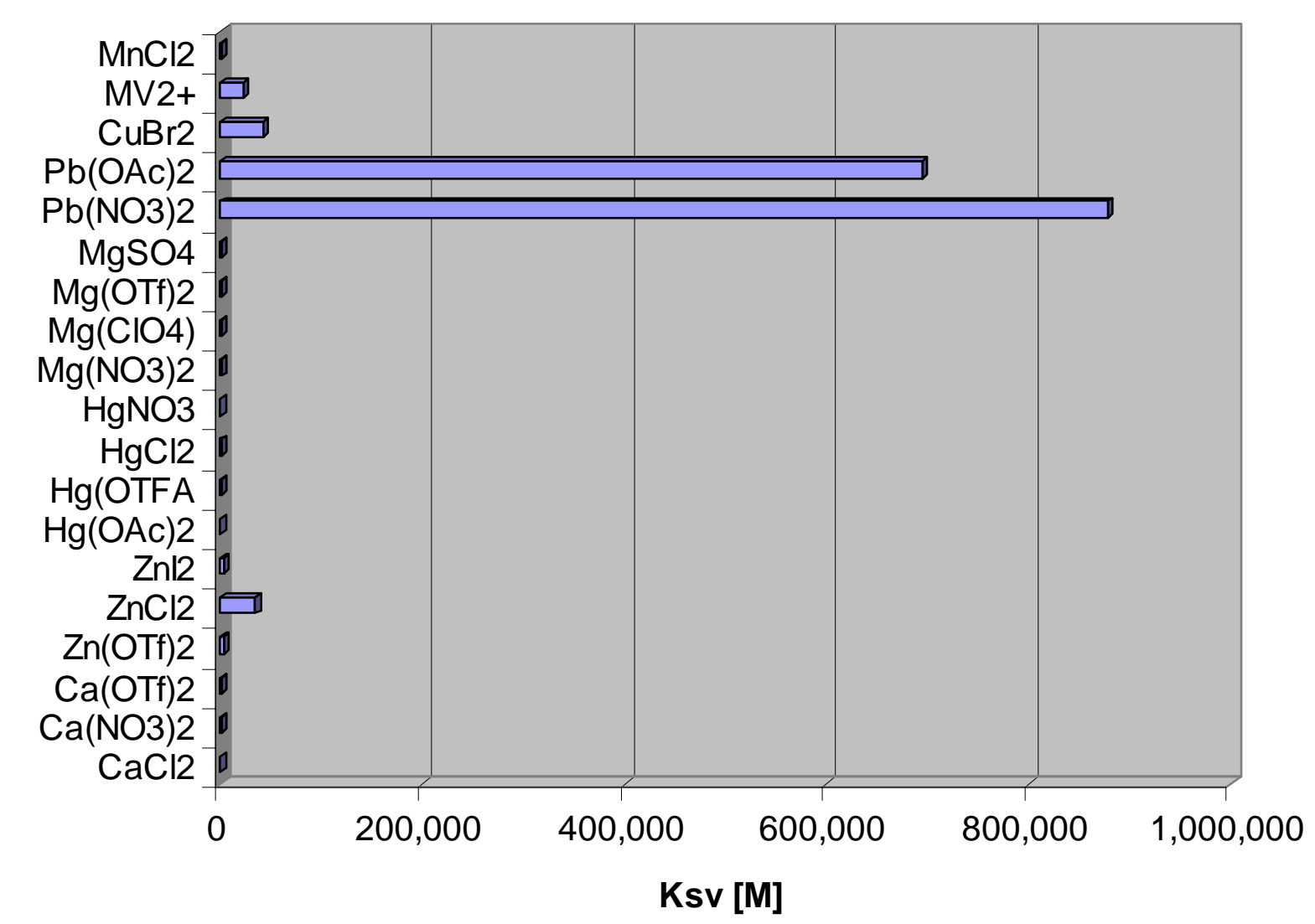

* PIPES : 1,4-piperazinebis(ethane-sulfonic acid, sodium salt) 
Figure 2. Stern-Volmer constants of the quenching experiments of polymer 4 in $0.01 \mathrm{M}$ phosphate buffer $(\mathrm{pH}=7.2)$.

\section{PPE-COOH in phosphate buffer}

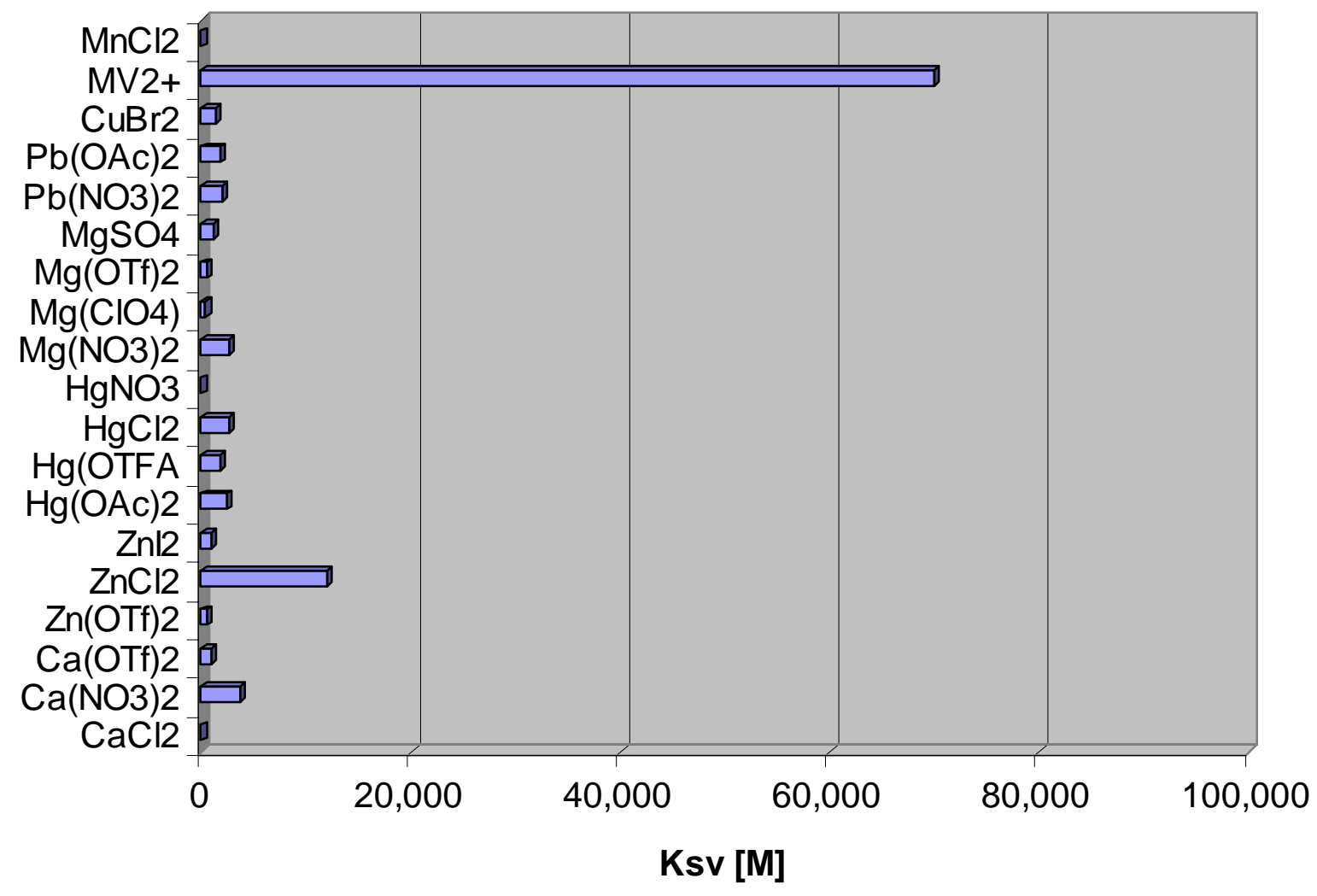


Figure 3. Fluorescence quenching experiments of polymer $\underline{4}$ with $\mathrm{Pb}\left(\mathrm{NO}_{3}\right)_{2}$ and $\mathrm{Pb}(\mathrm{OAc})_{2}$ in $0.1 \mathrm{M} \mathrm{KClO}_{4}$ and PIPES buffer.

\section{$\mathrm{Pb}\left(\mathrm{NO}_{3}\right)_{2}$}
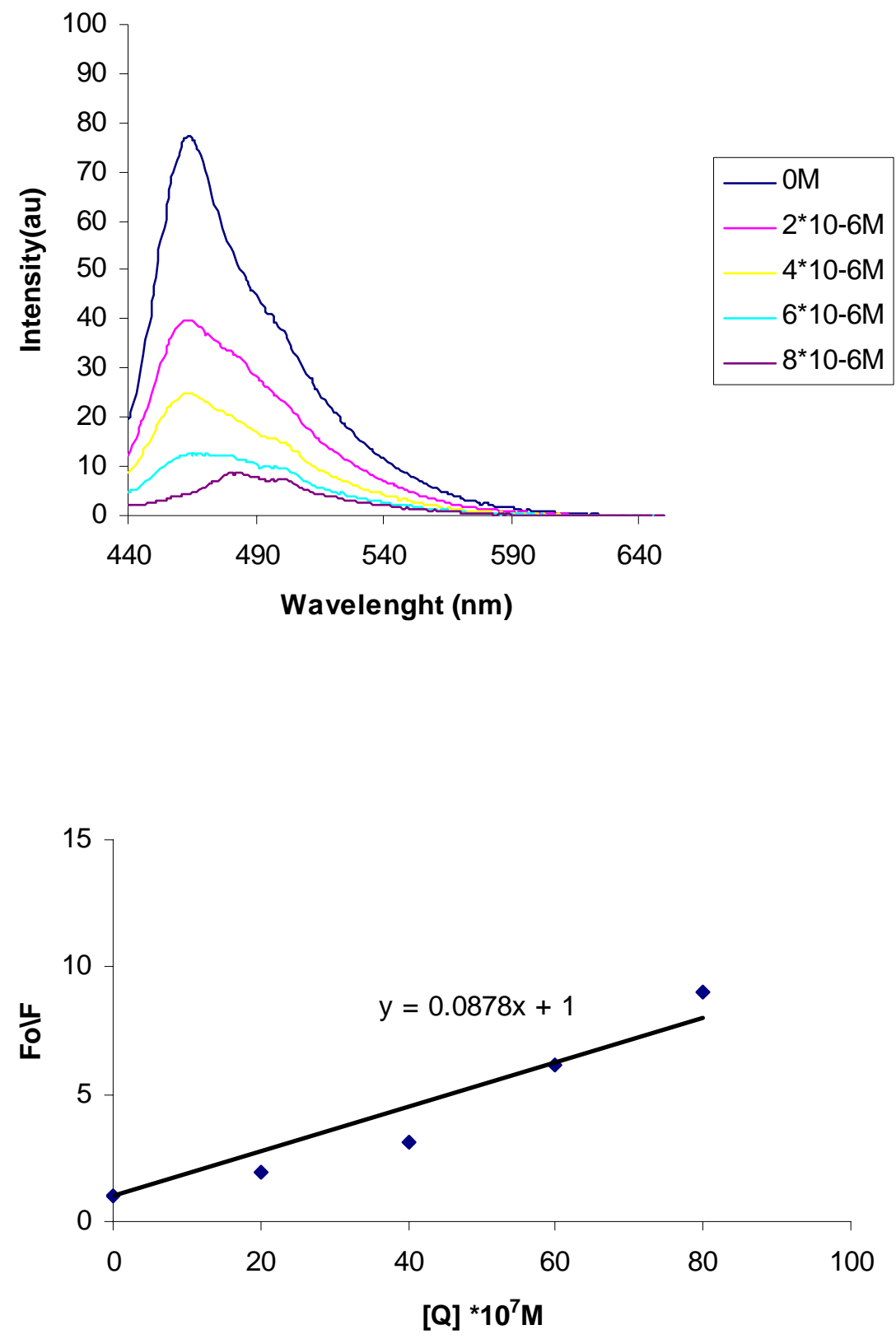
$\mathrm{Pb}(\mathrm{OAc})_{2}$
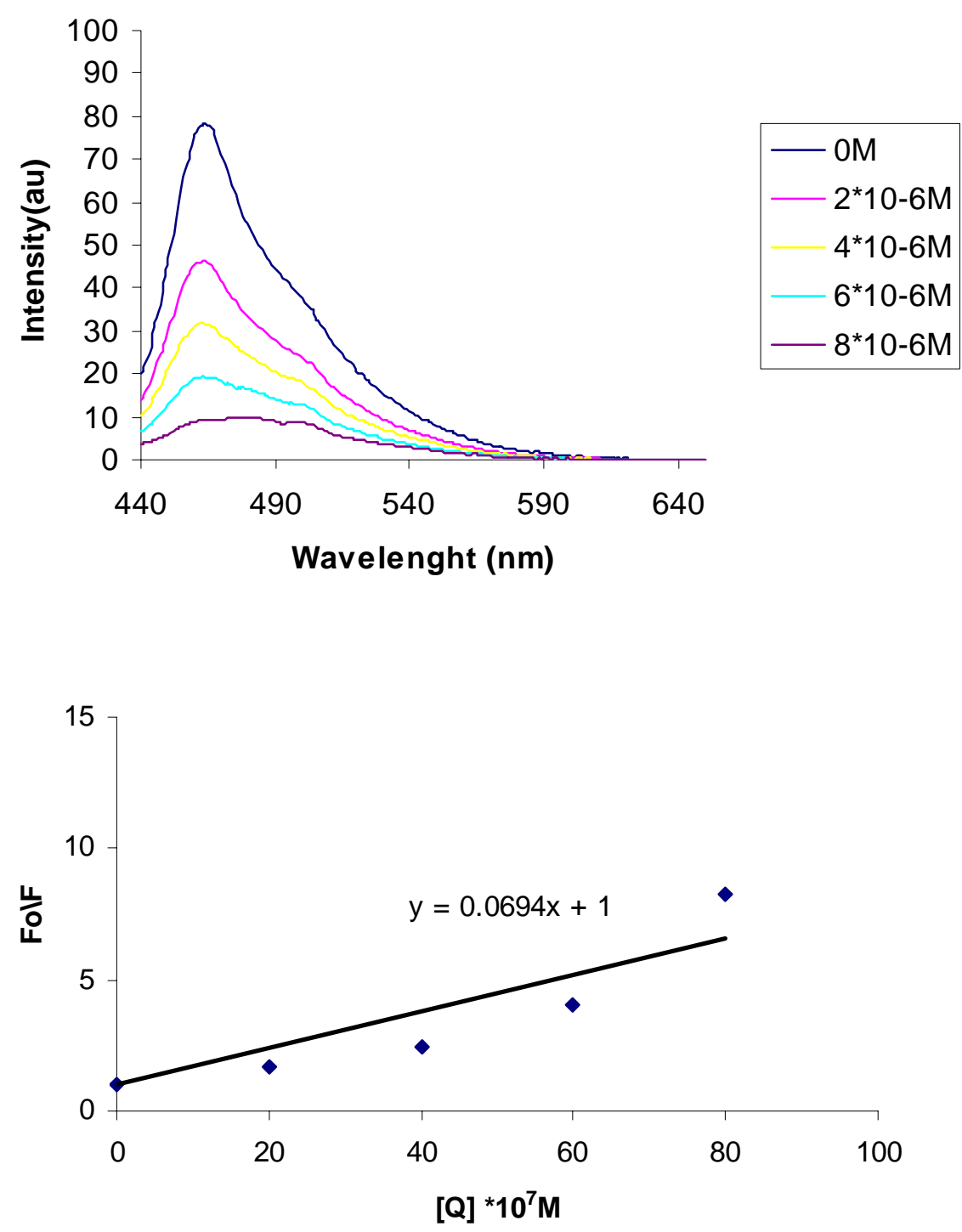
Figure 4. Fluorescence quenching experiments of model compound 5 with $\mathrm{Pb}\left(\mathrm{NO}_{3}\right)_{2}$ and $\mathrm{Pb}(\mathrm{OAc})_{2}$ in $0.1 \mathrm{M} \mathrm{KClO}_{4}$ and PIPES buffer.

\section{$\mathrm{Pb}\left(\mathrm{NO}_{3}\right)_{2}$}
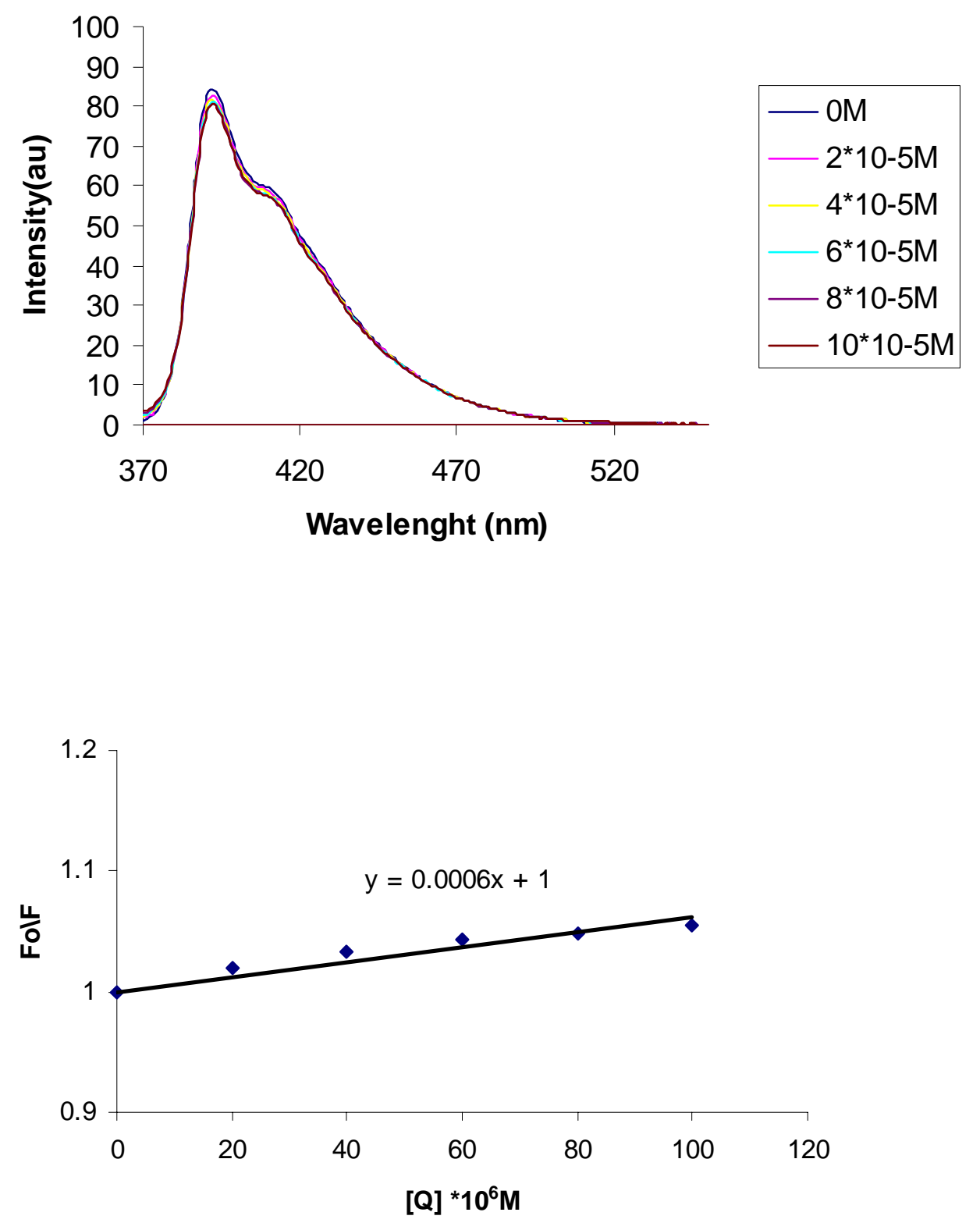


\section{$\mathrm{Pb}(\mathrm{OAc})_{2}$}
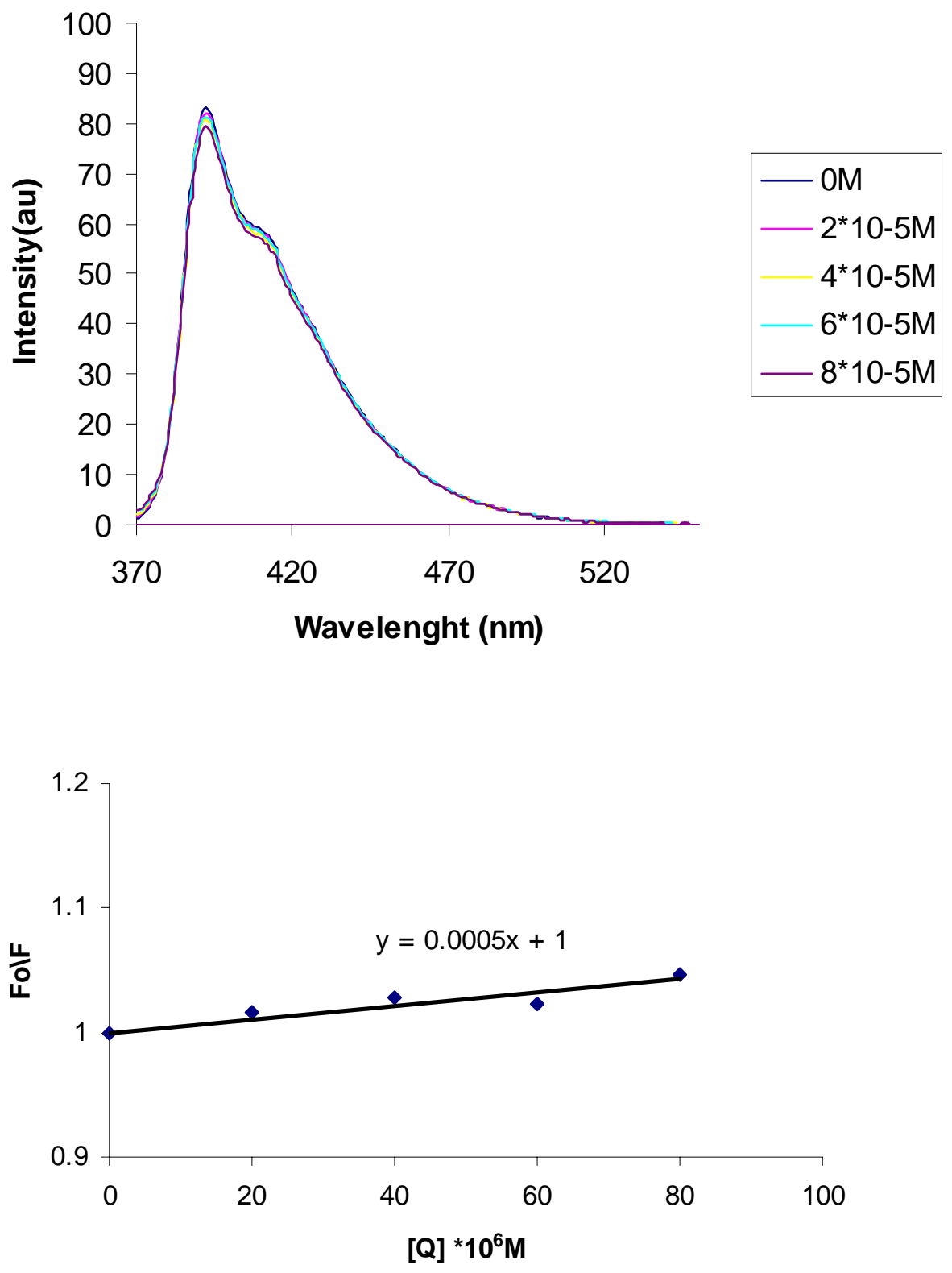